Osmanlı Bilimi Araştırmaları XIX, ‘Savaş ve Bilim’ Özel Sayısı (2018): 1-20

Araştırma makalesi / Research article

\title{
TOXICOLOGY IN POISONOUS YEARS: SÜMUM VE TESEMMÜMAT, DAMASCUS / BEIRUT 1918
}

\author{
ZEHIRLI YILLARIN TOKSIKOLOJISİ: \\ SÜMUM VE TESEMMÜMAT, ŞAM / BEYRUT 1918
}

Şeref Etker

\begin{abstract}
Dr. Süleyman Rifat (Suleiman Rifaat) graduated from the Civilian Medical School in Istanbul in 1906. In 1909 he was elected by the Ministry of Education to study in Germany. Süleyman Rifat attended the Institute of Pharmacology in Berlin and specialised in pharmacodynamics, toxicology and immunology. After his return in 1913 he was appointed to Palestine as health authority in Jerusalem. In the same year he joined the staff of the Ottoman Medical School in Damascus as professor of materia medica and therapeutics. With the beginning of the First World War Süleyman Rifat was conscripted to serve in the IV ${ }^{\text {th }}$ Army in the Sinai. He was the instructor for the cacolet transport services, and participated in the First Battle of the Suez Canal 1915. When the Ottoman Medical School was relocated in Beirut Dr. Süleyman Rifat was discharged to join its staff as professor of pharmacodynamics and therapy. Here he edited a compendium on poisons and intoxication consisting of tables, entitled Sümum ve Tesemmümat (Poisons et Empoisonnements). Certain elements of this text relates to the chemical warfare engaged by the British forces in the Second and Third Gaza Battles in 1917. Dr. Süleyman Rifat lived in Beirut after the Great War and converted to the Baha'i Faith.
\end{abstract}

Key words: Süleyman Rifat, Suleiman Rifaat, poisons, intoxication, Sümum ve Tesemmümat, Ottoman Civilian Medical School in Damascus, Ottoman Medical Faculty in Beirut, chemical warfare, Baha'i Faith.

Geliş / Received 10.10.2018; Kabul / Accepted 13.11.2018

Kaynak göster / Cite this article as

Etker, Şeref. "Toxicology in Poisonous Years: Sümum ve Tesemmümat, Damascus / Beirut 1918." Osmanlı Bilimi Araştırmaları XIX, ‘Savaş ve Bilim’ Özel Sayısı (2018): 1-20.

DOI 10.30522/iuoba.469295

Yazar bilgileri / Affiliations

Etker, Şeref. MD, İstanbul, Türkiye. serefetker@gmail.com

ORCID ID 0000-0001-6966-8816

Teşekkür / Acknowledgements

I am grateful to Dr.phil. Necati Alkan, Otto-Friedrich-Universität Bamberg, Germany, for guiding me to the relevant archival material. 


\section{Öz}

Dr. Süleyman Rifat, Mekteb-i T1bbiye-i Mülkiye'yi 1906 yllında bitirdikten sonra, Maarif Nezareti tarafından eğitim için, 1909'da Almanya'ya gönderildi. Berlin'de farmakodinami, toksikoloji ve bağışıklık bilimi üzerinde çalıştı. İstanbul'a 1913 yılında döndükten sonra Kudüs'e tayin edildi. Aynı yıl içinde, Şam Mekteb-i Trbbiye-i Mülkiyesi'ne Müfredat-1 Tıb ve Fenn-i Tedavi Muallimi oldu. Süleyman Rifat, Birinci Dünya Savaşının başlangıcında Mükellef Yüzbaşı olarak IV. Orduda görevlendirildi. Sina'da kakule eğiticisi oldu. Birinci Süveyş harekatına katıldı. Beyrut Osmanlı Tıbbiyesi'nin açılması üzerine terhis olunarak Farmakodinami ve Tedavi muallimliğine atandı. Sümum ve Tesemmümat adını verdiği, tablolardan oluşan bir toksikoloji elkitabını 1918'de yayımladı. 1917'de İkinci ve Üçüncü Gazze muharebelerinde İngilizler tarafindan kimyasal mermiler kullanılmasının toksikoloji eğitim programına yansıdığı düşünülebilir. Savaştan sonra Beyrut'a yerleşerek serbest hekimlik yapan Süleyman Rifat Bahailiği benimsedi.

Anahtar sözcükler: Süleyman Rifat, zehir, zehirlenme, Sümum ve Tesemmümat, Şam Mekteb-i Trbbiye-i Mülkiyesi, Beyrut Osmanlı Trbbiyesi, Kakule Nizamnamesi, kimyasal savaş, Bahailik.

\section{Introduction}

Dr. Theodor Wiegand, the Director of Antiquities in Berlin and a doyen of Asia Minor archeology, was conscripted in the Great War as captain in the Etappe. He decided to serve in Turkey and masterminded the DeutschTürkische Denkmalschutzkommando for the surveillance of archeological sites in the Eastern Mediterranean theatre of war. ${ }^{1}$ While in Palestine, on October 23rd, 1916 he wrote to his wife Marie describing the sanitary conditions in Jerusalem in a sombre tone:

The Municipality has no water filters and the disinfection apparatus of the hospitals are useless as a result of mishandling. The cisterns are poorly cleaned, sewage drainage is often stagnant, food is insufficient. Many people are trying to survive with the support of others and religious charities. The market is badly stocked, because people in the countryside only sell for cash, which is hard to come by. The poor are selling furniture and beds to get food; their weakened bodies are even more susceptible to infections. Firewood is rare and expensive, so many are devoured by the cold. The city lacks proper water lines. All around the

1 Oliver Stein, "Archeology and Monument Protection in War: The Collaboration between the German Army and Researchers in the Ottoman Empire, 1914-1918," in Militarized Cultural Encounters in the Long Nineteenth Century: Making War, Mapping Europe, eds. Joseph Clarke and John Hornes (Cham: Palgrave Macmillan, 2018), 297-318. 
city are magnificent stone buildings belonging to pious foundations. Would not it be better to build efficient water lines instead of these castle-like hospices ? ${ }^{2}$

The last health authority (hükumet tabibi) of the al-Quds al-Sharif (Jerusalem) district before WWI was Dr. Süleyman Rifat. ${ }^{3}$ He had just returned from his studies in Germany, and, like Theodore Wiegand, Süleyman Rifat was conscripted in 1914. But unlike Dr. Wiegand, who was in his fifties when he joined the Landwehrartillerie based in Damascus, ${ }^{4}$ Dr. Süleyman Rifat, Lieutenant in the IV ${ }^{\text {th }}$ Turkish Army, was promoted Professor at the Ottoman 'Civilian School of Medicine in Damascus' (Şam Mekteb-i Tibbiye-i Mülkiyesi). ${ }^{5}$ As a municipality physician Süleyman Rifat would have spent more time on paper work, dealing with medico-legal issues and trying to communicate with The Porte, than dealing with the urban infrastructure with meagre resources at his disposal. Anything he could do to touch the daily lives of the people - or, as Wiegand envisioned, the establishment - in al-Quds in a year leading to WWI would have been a miracle befitting the Holy City !

The School of Medicine in Damascus closed down at the end of 1914 when the students and staff alike were drafted. The School re-opened in Beirut on the $15^{\text {th }}$ of September 1916 as the 'Ottoman Medical Faculty' (Beyrut Osmanlı Tibbiyesi / Faculté de médecine ottomane de Beyrouth) ${ }^{6}$ following an

2 "Professor [Viktor] Schilling, die Hygieniker der 4. Armee, schildert mir die sanitäre Lage in Jerusalem... Die Municipalität hat keine Filter und die Desinfektionsapparate der Hospitäler sind infolge der verkehrten Behandlung unbrauchbar. Die Zisternen sind schlecht gereinigt, die Kanäle vielfach verstopt, die Nahrungsmittel nicht ausreichend. Viele Menschen lebten vom Fremdenbesuch und von der religiosen Wohltätigkeit. Der Markt ist schlecht versorgt, weil die Leute auf dem Lande nur gegen Hartgeld verkaufen wollen, und dies ist verschwunden. Arme Leute verkaufen Möbel und Betten, um Nahrung zu bekommen, der geschwächte Körper ist der Infektion natürlich viel zugänglicher. Brennholz ist selten und teuer, so wird vieles kalt verschlungen. Es fehlt an einer anständigen Wasserleitung. Rings um Stadt erheben sich großartigsten Steinpaläste frommer Stiftungen. Wäre es nicht besser, statt burgähnlicher Hospize eine vernünftige Wasserleitung zu bauen ?" Theodor Wiegand, Halbmond in Letzen Viertel. Briefe und Reiseberichte aus der alten Türkei von Theodor und Marie Wiegand 1895 bis 1918, ed. Gerhard Wiegand (München: Bruckmann, 1970), 193 'Sanitäre Zustände in Jerusalem.'

3 The name is also transcribed as Suleiman or Suleyman Rifaat.

4 Dr. Theodor Wiegand (1864-1936), Professor and 'Leiter der Antikenabteilung der Königlichen Museen in Berlin' since 1911. After 1st November 1916 he was 'Hauptmann der Landwehrartillerie im AsienKorps das Deutsch-Türkische Denkmalschutzkommando'. v. Th. Wiegand, "Denkmalschutz und kunstwissenschaftliche Arbeit während des Weltkrieges in Syrien, Palästina und Westarabien," Zeitschrift für bildende Kunst (Leipzig) 54 (1918/19): 278-293; Wissenschaftliche Veroffentlichungen des deutsch-türkischen Denkmalschutz-Kommandos, Heft I, ed. Theodor Wiegand (Berlin: W. de Gruyter, 1920); Suriye ve Filistin ve Garbi Arabistan Abidat-ı Atikesi / Alte Denkmäler aus Syrien, Palästina und Westarabien, eds. Ahmed Djemal Pascha and Theodor Wiegand (Berlin: Verlag Georg Reimer, 1918).

5 Dr. Ali Riza Atasoy (1875-1951) a contemporary Professor of dermatology at Damascus, gives the date of his assignment as 'after the appointment of Dr. Hasan Reşad [Sı̆̆ındım] as Director on November 20th, 1913,' A. Rıza Atasoy, Şam Türk Tıbbiye Mektebi Tarihi (Istanbul: Istanbul Üniversitesi Tıp Tarihi Enstitüsü, 1945), 16.

6 The renaming of the medical school was obviously a political move to suceed the Faculté française de médecine de Beyrouth. 
accord between the Ministry of Education and the IV ${ }^{\text {th }}$ Army Command. The institution and its facilities were brought under the administration of the Army and the conscripted professors were given leave to teach. ${ }^{7}$ Dr. Süleyman Rifat was chosen to be the 'Professor of pharmacodynamics and therapeutics' in the new Medical Faculty.

\section{A camel-back doctor with a 'face mask'}

Süleyman Rifat was born in 1884 in Istanbul to a religious family. His father Mehmed Ragıb Efendi from Zishtovi (presently Svishtov in Bulgaria) was a senior of the Kadiriye/Qadiriyya order. ${ }^{8}$ Süleyman Rifat entered the Civilian School of Medicine (Mekteb-i Tibbiye-i Mülkiye) in Istanbul in 1900. Graduating with honors in 1906 he qualified as clinical assistant. In 1908 he was appointed as the municipality physician to Yenişehir in Bursa. Subsequently, Dr. Süleyman Rifat was elected for specialized training in Germany to become one of the young generation of professors at the reformed Istanbul Medical Faculty. ${ }^{9}$

7

Atasoy, Şam Türk Tıbbiye Mektebi Tarihi, 30. Atasoy, mentions a telegram from the Ministry of Education in December 1916 in this regard.

8 BOA. DH.SAİDd.157/103.1302 Zilhicce 29 [9 Ekim 1885]. "19 Ağustos 322 [1 Eylül 1906] tarih ve 747 numerolu tababet diplomasını aldığı gibi, [Mülki] Mekteb-i Tıbbiyeden birincilikle neşet eylemekle mektebin Seririyat-1 Viladiye ve Cerrahiye-i Nisaiye ve Cildiye ve Efrenciye şubelerile [Haseki] Nisa Hastahanesine iki sene müddet devam edüb bu şubelerde kesb-i mümarese ve ihtisas eylediğine mutazammın tasdikname almışdır. Türkçe ve Fransızca tekellüm ve kitabet eylediği ve Arabi ve Farsi ve Ermenice ve İngilizce ve Almancaya biraz aşina idügü tercüme-i halinde mezkurdur... Mumaileyh, 31 Ağustos 325 [13 Eylül 1909] tarihinde Maarif Nezareti tarafından bera-yı tahsil Almanya'ya izamı münasebetile memuriyetinden infikak idüb aidat-1 tekaüdiye ve tevkifat-1 saireden ilişiği olmadığı gibi, müddet-i memuriyeti tarafindan cansiperane hüsn-i hizmet ve gayret idüb ikdam ve mesaisi ve hüsn-i ahlak ve sireti musaddak olduğu 17 Eylül 325 / 30 Eylül 1909 tarihinde Almanya'ya muvassalatile Berlin müessese ve hastahanelerinde ve Londra'da fenn-i tedavi ve edviyeye dair: farmakaloji, toksikoloji, seroloji, muafiyet, tedavi-yi kimyevi, tedavi-yi tecrübevi, tahlilat-1 keyfiye ve kemiyet-i edviye, tedavi bil-ma ve bil-mesh ve bil-elektrikiye ve bil-ziya ve bil-radyum, emraz-1 dahiliyenin tedavi ve usul-i müdavatı, tedavi-yi mihaniki, hıfzıssıhha ve bakteriyoloji, nebatat, ağdiye ve edviyenin muayene-i hurdebiniyesi, tufeyliyat, emraz-1 intaniye ve muhtelifenin usul-i tedavisi ve asab masaj1 [Nervenmassage] ve tedavi-yi seretan kısımlarında ameli ve nazari kesb-i ihtisas ve tezyid-i malumat etdiğini 16 Haziran 325 / 29 Haziran 911 tarihinde Berlin'de Berlin Fizyoloji Cemiyeti azası tayin kılındığı ve Dersaadet'de zuhur eden kolera münasebetile Maarif Nezareti canibinden verilen ruhsat üzerine İstanbul'a avdetle 6 Teşrinisani 328 [19 Kasım 1912] tarihinden 12 Kanunusani 328 [25 Ocak 1913] tarihine kadar Dördüncü Daire-i Belediye kolera vukuatında ifa-yı hüsn-i hizmet etdiği ve 12-17 Mart 329 / 26-30 Mart 913 tarihinde yine Berlin'de Beynelmilel Fizyoloji ve [14] Haziran 329 / 27 Haziran 913 tarihinde keza Berlin'de Asab Masajı Cemiyeti azalıklarına tayin olunduğu ve 26 Temmuz 329 / 8 Ağustos 1913 tarihinde ikmal-i tahsil ederek Berlin'den müfareket eylediği ve Almanya'da tahsilde bulunduğu müddetce şehri üçyüz Frank tahsisat verilüb 1 Ağustos 328 tarihinden itibaren de yalnız yüzde üç harb vergisi tevkif edildiği ve 27 Teşrinisani 329 [10 Aralık 1913] tarihinde İntihab-1 Memurin-i Sıhhiye Komisyonu kararile ve iki bin beşyüz guruş maaşla Kuds-i Şerif Sancağı hükumet tabibliğine tayin kılındığı Sıhhiye Müdiriyet-i Umumiyesi Sicil Şubesinin 27 Teşrinisani 329 tarihili vukuat pusulasında bildirilmişdir."

9 Atasoy, explained that Dr. Süleyman Rifat was sent to Germany at the behest of the Ministry of Education, Atasoy, Şam Türk Tibbiye Mektebi Tarihi, 16. 
Dr. Süleyman Rifat arrived in Berlin in September 1909 to study pharmacology, toxicology and immunology. He took the opportunity to attend the laboratories of physiology, chemistry, bacteriology and the departments of experimental medicine, and physical therapy where he became particularly interested in the Nervenpunktmassage technique. In 1911 he was elected member of the Berliner physiologische Gesellschaft. He also travelled to London for his observations.

In the conflagration of the Balkan Wars cholera devastated the populace. It was mid-November 1912 when Suleiman Rifat was summoned to Istanbul to aid in the containment of the epidemic. He was back in Berlin by the end of January 1913 to complete his research on the pharmacodynamics of narcotics (Cocaine and Ecgonine). ${ }^{10}$

Süleyman Rifat returned from Germany in the August of 1913. He had had almost four years of medical training in Europe. On December 10th, 1913 he was appointed to Palestine as health authority in the district (sanjak) of alQuds al-Sharif / Jerusalem. Shortly thereafter he became the Professor of materia medica and therapeutics (Müfredat- $T$ T b ve Fenn-i Tedavi Muallimi) ${ }^{11}$ at the Medical School in Damascus. With the beginning of World War I, Dr. Süleyman Rifat was posted in the Sinai as reserve Lieutenant (mükellef Yüzbaşı), and participated in the Second and Third Suez Canal campaigns in the summer of $1916 .{ }^{12}$ In the same year he compiled a regulation for the transport of the sick and wounded with camels (Kakule Talimatnamesi), ${ }^{13}$ comprising organisation and column formation. ${ }^{14}$

10 Suleiman Rifàtwachdani [Konstantinopel] (aus der Pharmakologischen Institut der Universität Berlin), "Das Schiksal des Cocains und Ekgonins im Organismus," Biochemische Zeitschrift 54, 1/2(1913): 83-91 [Eingegangen am 29. Juni 1913]. It is unknown why Süleyman Rifat chose to write his name as 'Rifàtwachdani'. A sufi connotation to the epithet 'wachdani / wahdani' : unity; 'wahdaniyya': unification, can be suggested.

11 Atasoy, Şam Türk Tibbiye Mektebi Tarihi, 16. Photograph IRCICA FAV.00.00.03 (Dr. Ali Vehbi Türküstün koleksiyonu, 3) Inauguration of the new building of the Medical School in Damascus on 21 March 1914 ('Şam Mekteb-i Tıbbiye-i Mülkiyesi resm-i küşad günü, 8 Mart 1330 [21.03.1914]'). Professor Süleyman Rifat is seated in the centre, $8^{\text {th }}$ from right. Reproduced in, Ekmeleddin İhsanoğlu, Al-Muassasat al-sihhiyah al-Uthmaniyah al-hadithah fi Suriyah: al-mustashfayat wa-Kulliyat Tibb alSham [Modern Ottoman Medical Institutions in Syria: Hospitals and Damascus Medical School] (Amman: Lajnat Tarikh Bilad al-Sham, 2002), ill. 29. (İhsanoğlu, translated Medical School as Kulliyat Tibb. Medical Faculty and 'Şam Tıp Fakültesi' as Medical College is a more appropriate appellation for this school.)

12 Dr. Süleyman Rifat was an instructor for the 'Kakule corps training center' formed in the IVth Ottoman Army ['Dördüncü Ordu-yı Hümayun Menzil Müfettişliği Kakule Sihhiye Mektebi'] prior to the Second Suez Campaign of the Ottoman Army. Atasoy, gives the title as 'Vesait-i nakliye tebabeti,' (transport medicine), which would make him one of the pioneers of the field, v. Atasoy, Şam Türk Tibbiye Mektebi Tarihi, 29.

13 Kakule Talimatnamesi, ed. Süleyman Rifat (Beersheba? 1332/1916 ? 16x20.5 cm. 24 p., 2+5 doublepage diagrams, 10 plates (ill.)) 
Dr. Süleyman Rifat returned to Beirut when the Ottoman Medical School was re-located in the premises of the St. Joseph Faculté de médecine et de pharmacie (on rue de Damas). From then on he was a 'consultant' for the IV. Army Hospital in Beirut, where he also held the title of 'Professor for neurological and internal diseases, therapeutics and intoxications'. ${ }^{15}$

Professor Suleyman Rifat returned to Istanbul in the beginning of April 1919 after the Ottoman Medical School in Beirut was closed down on the $4^{\text {th }}$ of October 1918 at the end of WWI. He was eligible to join the staff of the Faculty of Medicine of the Ottoman University in Istanbul as 'associate professor' (muallim muavini), together with his other colleagues. ${ }^{16}$ But the only information on Süleyman Rifat for this period is his appearance in a meeting at the Baha' $i$ center in the Fatih district of Istanbul, in a group photograph dated 22 April 1919. ${ }^{17} \mathrm{He}$ had accepted the Baha'i Faith, ${ }^{18}$ and would be moving back to Beirut, possibly to live closer to the 'Bab' in Haifa. ${ }^{19}$

\footnotetext{
Süleyman Rifat's contribution is acknowledged in the introduction: "Bunun tahrir ve vücuda getirilmesi hususunda Kakule Sihhiye Müfrezesi Mektebi muallimi [ve] Beyrut Osmanlı Tıb Fakültesi muallimlerinden mükellef Yüzbaşı Doktor Süleyman Rifat Bey’in büyük himmetleri geçmişdir.” Dr. Süleyman Rifat himself features in all 10 illustrations appended to the text. Also v. Nuran Yildirım, “Osmanlı Ordusunda Kakule Sıhhiye Bölükleri,” V. Türk Tıp Tarihi Kongresi Bildirileri (Ankara, 16-18 Mart 1998), eds. Esin Kahya, et.al. (Ankara: Ankara Üniversitesi, Gülhane Askeri Tip Akademisi, Türk Tip Tarihi Kurumu, 1999), 163-187.
}

14 Adopted from French cacolet. Apparently, this a Turkish model modified from Dr. D.-J. Larrey's ambulance volante: "On transporte aussi des malades à dos de chameau, dans chaises à porteurs suspendues aux flancs de l'animal, et disposées pour reservoir une personne assise ou couchée. La Turquie avait exposé un cacolet dans ce genre," in David Gruby, "Appareils et instruments de 1'art médical (Études sur l'Exposition de 1867)," Annales et archives de l'industrie au XIXe siècle nos. 36-37 (25 Janvier 1869): 279

15 Dr. Süleyman Rifat was the Professor of pharmacodynamics and therapeutics at the Beirut Ottoman Medical Faculty. Presumably, 'traitements des maladies internes et nerveuses, des remèdes et des poisons' denotes the relevant subject matters of his courses.

16 There were two pharmacologists from the Damascus Medical School: Ligor (Grigorios) Taranakides and Mustafa Hakkı Nalçacı, who were reinstated in the Chemistry Departments of the Faculties of Science and Medicine Ottoman University in Istanbul, respectively, v. Emre Dölen, Eczacı Kimyager Anorganik ve Analitik Kimya Müderrisi Ligor Bey (1877-1956) (İstanbul: Türkiye Kimya Derneği, 2017), and Emre Dölen, Umumi Kimya Müderrisi Mustafa Hakkı Nalçacı (1881-1953) (İstanbul: Türkiye Kimya Derneği, 2016.

17 İBB Atatürk Kitaplı̆̆

18 Necati Alkan, "The Young Turks and the Baha'is in Palestine," in Late Ottoman Palestine: The Period of Young Turk Rule, eds. Yuval Ben-Bassat and Eyal Ginio (London: I. B. Tauris, 2011), 259-278; Necati Alkan, Dissent and Heterodoxy in the late Ottoman Empire: Reformers, Babis and Baha 'is (Istanbul: The Isis Press, 2008), 185.

19 'Dr. Suliman [sic] Rifat, a Turkish doctor from Constantinople' is already at Haifa on 16 November 1919, George O. Latimer, The Light of the World (Boston: self-published, 1920), 25.

'[A] Bahai Turk named Dr. Suleiman Rifaat Bey, whose home is in Beirut came to visit Abdul-Baha.' Star of the West, 12, 19 (March 2, 1922), 302. 'Letter from Abbas Adib to Dr. Zia M. Bagdadi (Jan. 4, 1922)'. https://s3.amazonaws.com/starofthewest/SW_Volume12.pdf 


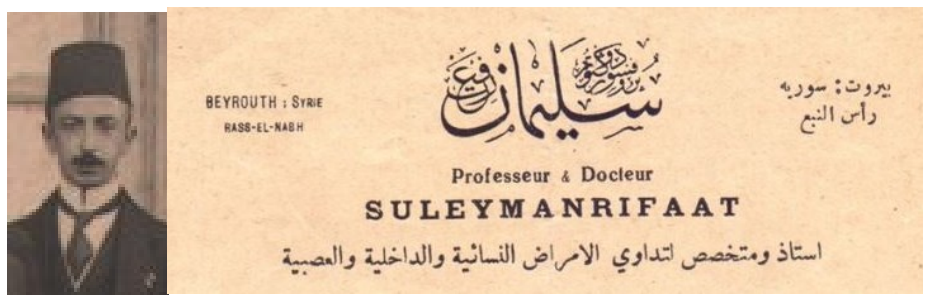

Prof. Dr. Süleyman Rifat (Istanbul, 1919). ${ }^{20}$ Title in Beirut c. 1925 (Private Archive).

Hardly anything is known about the later years of Dr. Süleyman Rifat, except that he had a medical practice for 'gynaecology, internal medicine and neurology' in the Rass al-Nabh district of Beirut. A recollection from the 1930s portrays him as a senior Baha' $i,{ }^{21}$ and relates how the senior Dr. Süleyman Rifat liked to present himself as a former court physician. ${ }^{22}$ Prof.Dr. Ali Riza Atasoy, his colleague from the Damascus years, notes that by 1945 he was still in private practice in Beirut. ${ }^{23}$

Süleyman Rifat's lecture notes would have been published and circulated in Damascus. Commonly, students took notes in shorthand, the tutor edited the manuscript, which was then conveniently printed by lithography - on the cheapest paper in the market. Dr. Atasoy, mentions a standard textbook on therapeutics (Fenn-i Tedavi) edited by Dr. Süleyman Rifat. ${ }^{24}$ Interestingly, there are no other bibliographical references to this volume. The language of instruction in the Ottoman medical schools in Damascus and Beirut was Turkish, but the lingua franca of scientific communication was French. Süleyman Rifat was fluent in a number of languages and may also have written articles and essays in Arabic. ${ }^{25}$

20 İBB Atatürk Kitaplı̆̆ı, Bel_Mtf_001694.pdf.

21 Sait Hurşid, Son Vapuru Kaçıranlar, yay.haz. M. Bülent Varlık (İstanbul: İletişim, 1999), 65. 'Doktor Süleyman Rifat Bey, Bahai tarikatına intisap etmişti. Anladığıma göre Bahailerin büyüklerinden sayılırmış.'

22 Hurşid, Son Vapuru Kaçıranlar, 64-65. The author relates a story he listened from Süleyman Rifat in which he believed to be poisoned with strychnine himself at the Palace! 'Doktor Süleyman Rifat Bey İstanbul'da Saray'ın doktorlarından biriymiş... Doktor Bey, bir hatırasını bize şöyle anlatmıştı: "Günün birinde Saray'dan atlı arabayla eve dönerken, dizlerimin üstüne koyduğum ellerime baktım. Ellerimin şiş olduğunu gördüm. Araba gidiyor, ben buz kesmiş gibi ellerime bakıyordum. Her bakışımda ellerimin daha fazla şişmiş olduğunu görüyordum; bütün vücudumun da şiş olduğunu seziyordum. Strikninle zehirlendiğimi anladım, ecelimin yakın olduğunu sandım. Vaktiyle birisinin, 'insan zehirlendiği zaman hareket etmezse ölümden kurtulabilir' dediğini hatırladım. Put gibi hareketsiz oturdum. Nihayet evime yaklaşınca şişler yavaş yavaş inmeye başladı ve kurtuldum." Atasoy, Şam Türk Tibbiye Mektebi Tarihi, 52 (Portrait). Atasoy, Şam Türk Tibbiye Mektebi Tarihi, 52. 'Fenn-i tedavi hakkinda klasik bir eseri vardır.'

25 According to the document cited above cf .2, by 1913, besides Turkish, Dr. Süleyman Rifat could read and write in French, and was familiar with the Arabic, Persian, Armenian, English and German 


\section{Poisons et Empoisonnements: Sümum ve Tesemmümat}

A toxicology compendium entitled Sümum ve Tesemmümat (Poisons and Poisoning) by Professor Dr. Süleyman Rifat has survived. ${ }^{26}$ The full title of this publication is: Müfredat-l Tıbdan En Mühim ve Kesir'ül-Vuku Sümum ve Tesemmümat Levhat-ı Tibbiyesi: Zehirler ve Zehirlenmeler (Poisons and Poisonings: The most significant and common poisons and intoxications encountered in medical practice formulated in tables for professionals). ${ }^{27}$ The French title is abridged as: Tableaux des Poisons et Empoisonnements. ${ }^{28}$ The size and design of this small book, with its tables printed on one (recto) face of each plate and unfolding like a scroll, was presumably prepared for bedside and on-site reference. One could surmise that the same tables in larger format were displayed on the walls of Dr. Süleyman Rifat's demonstration laboratory. Sümum and Tesemmümat remains as one of the earliest texts of modern toxicology in Turkish. ${ }^{29}$ At least one plate among the 19 that make up the book was printed a year earlier in Damascus. This leads us to conclude that the production Sümum ve Tesemmümat was commenced in Damascus by 1917. ${ }^{30}$

If we are to trust Atasoy for a 'classic' therapeutics textbook written by Dr. Süleyman Rifat, we need to consider that large volumes usually came out of press in 16-page signatures and were distributed as such. This would make it less expensive for the students. Plates, fold-outs and color diagrams were printed separately. The full title of Sümum ve Tesemmümat begins with 'Müfredat-ı Tibdan' which could be taken to mean that these tables (levhat-l

languages. After this date, having been in for four years in German and living Syria and Lebanon for as many years, he must have been fluent in German and Arabic.

26 The single extant copy is an ex libris from the personal library of the late Professor Dr. Ali Vehbi Türküstün (1877-1937).

27 Muallim Doktor Süleyman Rifat, Müfredat-ı Tıbdan En Mühim ve Kesir'ül-Vuku Sümum ve Tesemmümat Levhat-ı Tibbiyesi: Zehirler ve Zehirlenmeler. Beyrut Osmanlı Tıbbiyesi Emraz-1 Asabiye ve Dahiliye Tedavileri ve İlaçlar ve Zehirler Muallimi ve Dördüncü Ordu-yı Hümayun Beyrut Hastahaneleri Müşavir-i Seririsi (Beyrut: Tabbara Matbaas1, 1334-1918) (Turkish text in Arabic characters. 10.0 x 22.5 cm. 1 p. +19 foldout plates [22.5 x $34-45 \mathrm{~cm}]$.$) . No price indicated.$

Tableaux des Poisons et Empoisonnements par Prof. Dr. Suleiman Rifaat Bey, Professeur des traitements des maladies internes et nerveuses, des rèmedes et des poisons à la Faculté de Médecine ottomane (Beyrouth: Imp. Tabbara, 1334-1918).

29 Halil Tekiner, İ. İpek Boşgelmez, Gülin Güvendik, Ayşe Eken, Burcu Ünlü Endirlik, Emre Dölen, “Türkiye'de 1920'den günümüze kadar basılmış olan toksikoloji ders kitaplarının içerik ve terminoloji bakımindan incelenmesi" (A review of toxicology textbooks published in Turkey from 1920 to the present with regard to content and terminology), XI. Türk Eczacllık Tarihi Toplantısı, Kayseri, 25-28 Mayls 2014, Bildiriler / XI. National Conference on the History of Turkish Pharmacy, Kayseri, 25-28 May 2014, Proceedings, eds. Afife Mat ve Halil Tekiner (Kayseri: Erciyes Üniversitesi Eczacilik Fakültesi, 2016), 164-171.

30 It may be that the tables could not be printed to the satisfaction of the author at the Military Press in Damascus. Printing with the lithography technique is not type-set; handwriting is generally smaller and can be difficult to decipher. 
tıbbiye) were a part of the materia medica curriculum, or that the tables are from his book, possibly bearing the title Müfredat-ı Tıb ve Fenn-i Tedavi - similar to the title of the chair held by Süleyman Rifat in the Damascus Medical School, and therefore Müfredat- $\iota$ Tıb'dan (i.e. from the textbook Müfredat-ı Tib). The toxicology tables could also have been published separately, if the publication of the book could not be completed and an actual demand for the tables on poisons and poisoning subsisted, calling the printing of Sümum ve Tesemmümat a priority.

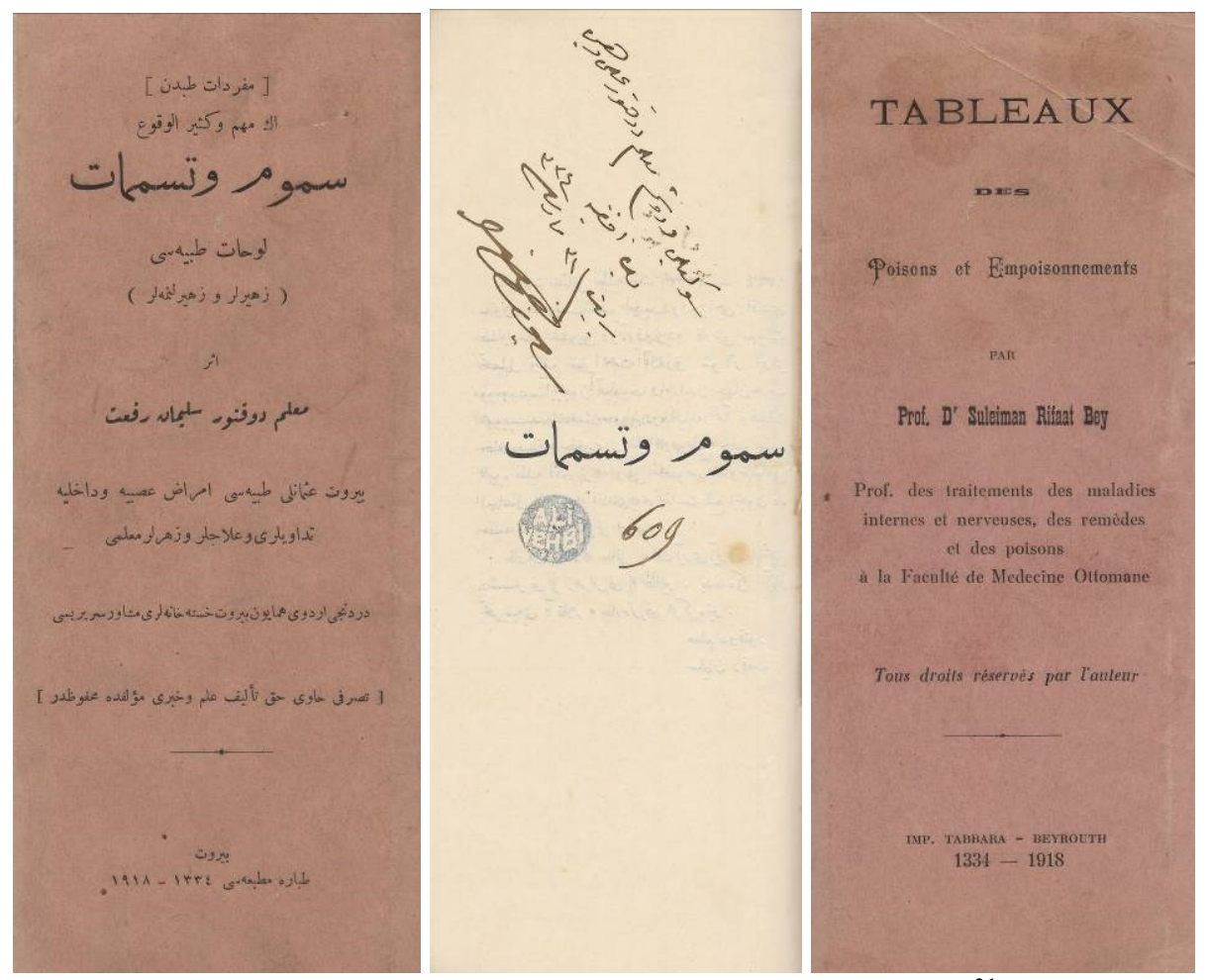

Sümum ve Tesemmümat. Title page, front and back covers. ${ }^{31}$

In his brief foreword Professor (muallim) Doctor Süleyman Rifat, points out that the publication of Sümum ve Tesemmümat is an outcome of the encouragment and appeal he received from the students of medicine and pharmacy at the Ottoman Medical Faculty in Beirut, during the academic year 1917-1918. He states that the tables were organised with the view of facilitating instruction and research, and acknowledges the contribution of his assistant Ismail al-Awsata Efendi of Damascus. Süleyman Rifat commends the

31 Author's dedication to Professor Dr. Ali Vehbi [Türküstün], Beirut, 31 March 1918: 'Sevgili Kardeşim Muallim Doktor Ali Vehbi Beyefendiye, Beyrut, 31 Mart 334.' 
publishers for their fine work, accomplished under the duress of the continuing World War and ensuing cost increases. ${ }^{32}$

The printing of Sümum ve Tesemmümat must have been completed by May 1918 before the final examinations of the year. If, Professor Dr. Süleyman Rifat undertook the editing of his book in the beginning of the same academic year, as he states in his Introduction, we should remember that this period corresponds to a decisive phase of the Great War in the Middle East between Third Gaza Battle in October-November 1917, the surrender of al-Quds (Jerusalem), and the fall of Baghdad to the Allies in March 1918.

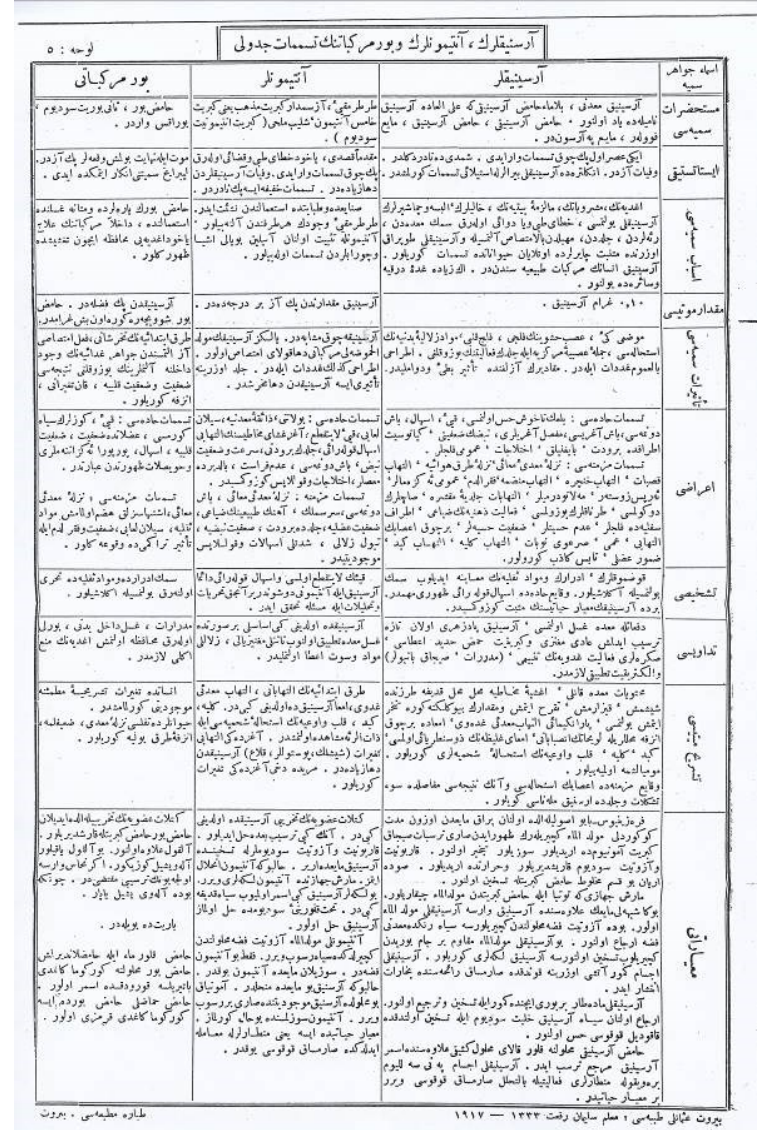

"Table 5 - Poisoning with Arsenic, Antimonies and Boron compounds" 33

32 Sümum ve Tesemmümat, [p. i]. 'Beyrut Osmanlı Tıbbiyesi'nin 1333-1334 seneleri tedrisatında tabib ve eczacı efendi talebelerimin teşvik ve arzularına karşı, suhulet-i tahsil ve tetebbu nazar-l ehemmiyete alınarak şu eser ibraz-ı mevcudiyet içün, açılub devam eden Cihan Harb-i Umumisinde mütehaddis suubet ve bahalılı̆̆a rağmen tevfikat-ı Hakla meydana çıkdl.' 
The titles of the tables emphasise 'the most significant' (en mühim) poisons, which, in practical terms, signifies the most common intoxications with potential lethality. A 'lethal dosis' is given for every poisonous/toxic substance included in the lists - a few exceptions are quicklime, veratrine, and cicutoxin of water hemlock. In each table the properties of the poisons are given in boxes forming columns. The characters in the descriptions are the equivalent of a Font 10, and the printing is clear with few misprints. (The latin characters used for some medical terms are somewhat larger.) The cover of the slim, pocket-size book is rather thin, but the tables were printed on thicker paper for heavy duty and bound with a single string.

There are some overlapping in the categorization of the intoxicants (v. Appendix), as between Tables 1 and 8,11 and 12, and 13 and 14. The length of the tables vary with the expansion of the content, from 34 to $45 \mathrm{cms}$. The length of the tables seem to correspond to the literature available to the author: the longest Table 17 is on internal diseases or what the author calls 'autointoxications'. The largest and most detailed cells cover reagents and chemical analyses (e.g. arsenic, chloroform, alcohol, picrotoxin, digitoxine).

The properties are summarised for each poison under the topics:

(A) Names of poisonous substance; (B) Commercial and other products containing the agent; ${ }^{34}$ (C) Statistics; (D) Etiology; ${ }^{35}$ (E) Lethal dosis; (F) Mechanisms of poisoning; (G) Symptomatology (Pathologie/Symptomatologie); (H) Clinical course of intoxication; ${ }^{36}$ (I) Prognosis (Pronostic); (J) Diagnosis; (K) Therapy (Therapie); (L) Pathological (postmortem) anatomy (Anatomo-pathologie); (M) Analyses and reagants. ${ }^{37}$

33 Levha 5: Arsinikler [sic], Antimonlar ve Bor Mürekkebatının Tesemmümat Cedveli. The note at the bottom of the table reads 'Beyrut Osmanlı Tibbiyesi, Muallim Süleyman Rifat 1333/1917, Tabbara Matbaası, Beyrut.'

34 Product information is not given in Tables 9, 11, 12, 16, 17 and 18.

35 Misspelled as 'Ethiologie' in Tables 17 and 18. French titles by author.

36 In tables $1,2,3$, and 8 .

37 In Table 17 there are two extra headings for: Intoxication by accumulation (Intoxications par retention) and Neoplastic intoxications (Noso-intoxications)] 


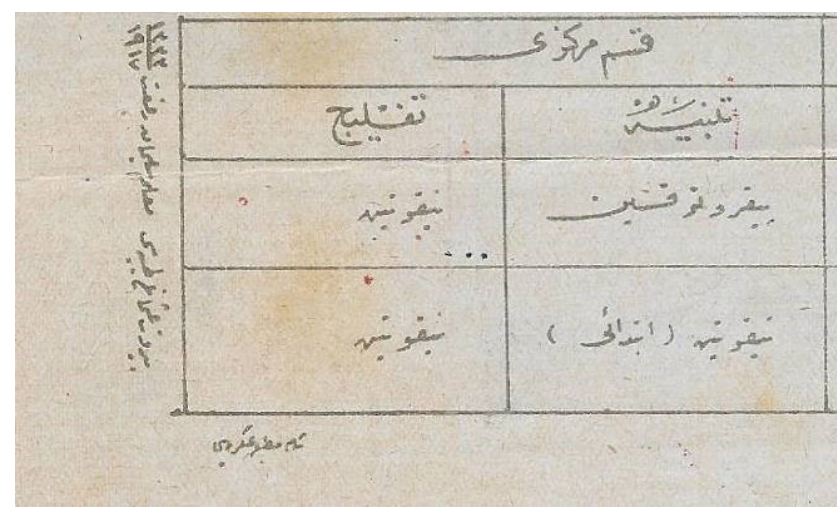

Caption at the bottom: Şam Matbaa-i Askeriyesi ${ }^{38}$

In reading Süleyman Rifat's toxicology notes one can infer from the text that he had a command of physiology and was adept in laboratory analyses. His descriptions of procedures under the heading 'miyarat' (lit. chemical reagents) are detailed. A number of instruments, such as the Mitscherlich and Marsh apparatuses are mentioned, together with certain electrochemical (tahlil- $i$ elektriki) and titrimetric analyses. He does, however, emphasise that in many instances the best method of diagnosis can be a 'refined olfactory sense'. ${ }^{39}$ There are other physical signs of note, such as a 'phosphorescent exhalation' of patients with phosphorus intoxication.

References to the works of Georg Dragendorff, Johann-Ludwig Casper, Ambroise Tardieu, and Oscar Liebreich on forensic chemisty (kimyeviye- $i$ adliye) are noted. Dr. Süleyman Rifat distinguishes between a 'chemist' and a 'specialist pharmacologist' and seems to assume the latter title for himself. 40 Süleyman Rifat cites his own published animal studies on Cocain (Table 10.4. L). ${ }^{41}$

Statistics are given in broad terms, such as 'mortality to-date', or 'half a century ago', and local incidences are referred to in passing, like 'intoxication with arsenic contaminated beers in England' ${ }^{42}$ Gaseous of acids such as 'fumes (duhan) or vapours (buhar)' of nitric and hydrocloric acid are indicated. Carbon monoxide poisoning is described in some detail (Table 8.2.) where Süleyman Rifat also mentions gases from explosives: smokeless gunpowder creates

38 Plate 18. 'Military Printers in Damascus'. On the left of table: Beyrut Osmanl Tibbiyesi (Beirut Ottoman Medical School) Muallim Süleyman Rifat 1333/1917.

39 Such as for chlorine: 'En hassas miyar ise hassas olan bir burun, yani hiss-i şammedir' (Table 4.1. M).

40 'Kimyageran tarafindan dikkatle ve saf olarak akonitin eşya-yl tahliliyeden çıkarllub mütehassıs farmakolog tarafindan miyarat-ı bedeniyesi elde edildikden sonra...' (Table. 12.3 M).

41 Ref. 7 above.

42 'Ingiltere’de arsinikli biralarla tesemmümat görülmüş̦tür’ (Table 5.1. C). 
carbon monoxide (CO) in abundance, and dynamite explosions produce up to ' $30 \% \mathrm{CO}, 20 \%$ carbonic acid, $10 \%$ methane, $9.8 \%$ nitrogen, $23 \%$ water vapour, and $9 \%$ anhydrous nitrogen', etc.

As a municipality physician Süleyman Rifat would have carried out numerous post-mortems of intoxications. His descriptions of pathological anatomy are quite specific. Incidentally, he mentions a 'cracking' sound of dissected renal tissue in a number of cases.$^{43}$ Lethal doses for gases are given in percentage, which makes it difficult to compare with the standards (miligrams and grams) of other intoxicants. Overall, poisoning treatment ( $\mathrm{K}$ 'tedavi') is symptomatic and largely deriving from the current toxicology literature.

\section{Chemical warfare in the Middle Eastern Front in WWI}

Dr. Süleyman Rifat, urges the use of special face masks ${ }^{44}$ against 'gases like chlorine, and other airborne irritant particles', ${ }^{45}$ and the 'employment of protective face masks' again in the case of bromium. ${ }^{46}$ Gas masks must have beeen available at the time when he penned his compendium, because he admonishes their use even when cleaning sewers and septic-tanks where hydrogen sulfide accumulation is suspected. ${ }^{47}$ Whether Süleyman Rifat had the notion of an imminent deployment of chemical weapons can not be gleaned from his writings, but chemical warfare was certainly in the minds of the officers since the major military campaigns of the Gallipoli War. ${ }^{48}$ So, it would not be surprising to find a picture of Lieut. Dr. Süleyman Rifat on camelback in the Sinai with a gas mask on his side !49

Yigal Sheffy, who has reviewed the accessible material on the supply of gas masks in the $\mathrm{IV}^{\text {th }}$ Ottoman Army (in Syria, Palestine, and Arabia), mentions a communication with Istanbul regarding provision as early as February 1917,

43 'Kilyeler ise üstüvanat ve fahmiyat-ı kalsiyum terakümünden bıçakla kesilirken kitırdar' (Table 6.1. M) and 'Kilyelerin bıçak altında gıcırdamast...' (Table 17.3. M).

44 The basic components of a gas mask are the face mask and attached filter. For types of gas masks in use in WWI, v., Benjamin A. Hill, Jr., "History of Medical Management of Chemical Casualties," in Medical Aspects of Chemical Warfare, ed. Shirley D. Tuorinsky (Washington, DC, Borden Institute, 2008), 84, fig. 3-5.

45 'Klor gibi gazat ile süfufat-ı muharrişiye içün, mahsus maskelerin yüze konması' (Table 4.1. K).

46 'Muhafiz yüz maskeleri istimali' (Table 4.2. K).

47 'Lağımları açub etmek esnasında maske takmak...' (Table 8.3. M).

48 Yigal Sheffy, "Asphyxiating Gas and the Gallipoli War: The Introduction of Chemical Warfare to the Middle East," Gallipoli in Retrospect 90 Years On / 90. Ylldönümünde Çanakkale Savaşlarını Düşünürken, ed. A. Mete Tuncoku (Çanakkale, Çanakkale Onsekiz Mart Üniversitesi Atatürk ve Çanakkale Savaşları Araştırma Merkezi, 2005), 225-233; Yigal Sheffy, "The Chemical Dimension of the Gallipoli Campaign: Introducing Chemical Warfare to the Middle East," War in History, 12,3 (July 2005): 278-317.

49 For an illustration of 'A medical officer going his rounds' on camel-back in the Egyptian Expeditionary Force, v. E. Dolev, p. 90. 
before the Second Gaza Battle. ${ }^{50}$ It has now been established that gas masks were distributed to the Turkish troops in the days leading to the Third Gaza Battle at the and of October 1917.51

There are two extant instruction booklets for officers and soldiers, respectively, on 'Chemical Warfare and Protection from Chemical Weapons' published by the Turkish Ministry of War during WWI, both issued in 1916. ${ }^{52}$ The use of gas masks are described at length: Made of the impermeable fabric this gas mask with two metal-rimmed viewers (iki madeni çerçeve ile gözlükler) and a filter fixed to a third aperture (p. 8) was a regular German model, and must have been supplied by the Ottomans' German allies who had already engaged in chemical warfare in the Eastern Front as early as January 1915 that is around the days of the First Suez Canal offensive. ${ }^{53}$

Sheffy, in his research based primarily on British sources, has concluded that during the Second and Third Gaza Battles in 1917, both lacrimatory $\left(\mathrm{SK}^{54}\right)$, and asphyxiating gases $\left(\mathrm{CBR},{ }^{55} \mathrm{VN},{ }^{56}\right.$ and $\mathrm{PS}^{57}$ ) were used against the $\mathrm{IV}^{\text {th }}$ Ottoman Army. ${ }^{58}$ Chemical shells were also fired at Akaba. Conceivably, climatic circumstances rendered the chemical shelling ineffective to some degree. ${ }^{59}$ Yet, without the reports and accounts of the Turkish and German

50 Yigal Sheffy, "Chemical Warfare and the Palestine Campaign, 1916-1918," The Journal of Military History, 73 (July 2009): 812. Sheffy quotes his source as: Birinci Dünya Harbinde Türk Harbi, IV. Cilt I. Kısım, Sina - Filistin Cephesi, Harbin Başlangıcından İkinci Gazze Muharebeleri Sonuna Kadar (Turkey's War in WWI: The Sinai - Palestine Front, from the Beginning of the War to the end of the Second Gaza Battle), T.C. Genelkurmay Başkanlığı ATASE yay. (Ankara: Genelkurmay Basımevi, 1979), 488.

51 Yigal Sheffy, "Chemical Warfare," 833.

52 Zabitana Mahsus Gaz Muharebesi ve Gazlardan Korunma Hakkinda Talimat, İstanbul Matbaa-i Askeriye, 1332 [1916, 15 p.]; Gaz Muharebesi ve Gazlardan Korunma Hakkinda Talimat, Neferata Mahsusdur, İstanbul, Matbaa-i Askeriye, 1332 [1916, 15 p.]; Gaz Muharebesi ve Gazlardan Korunma Hakknda Talimatname, Neferata mahsusdur, [Second edition] Harbiye Nezareti Sahra Sıhhiye Müfettiş-i Umumiliği, İstanbul: Matbaa-i Askeriye, 1333 [1917], 23 p.

53 Steven J. Main, "Gas on the Eastern Front during the First World War (1915-1917)," Journal of Slavic Military Studies 28, 1 (Jan.-Mar. 2015), 99-132.

54 SK: Lacrimatory/tear gas: $75 \%$ ethyl iodoacetate and $25 \%$ alcohol.

55 CBR: carboxyl dichloride (Phosgene), arsenic (arsenous) chloride - in equal parts.

56 VN (Vincennite): 50\% hydrogen cyanide, 30\% arsenious trichloride, $15 \%$ stannic chloride and $\% 5$ chloroform.

57 PS: chloropicrin.

58 The chemical shells used during the Third Gaza Battle (30 $0^{\text {th }}$ October $-4^{\text {th }}$ November 1917) are summarized in a table which gives an overview of the battles, v. Yigal Sheffy, "Chemical Warfare" p. 831.

59 Yigal Sheffy, "Chemical Warfare" 818; Eran Dolev, Allenby's Military Medicine: Life and Death in World War I Palestine, London, I.B. Tauris, 2007, p. 36-38. 
officers on the ground it would be unfounded to dismiss biological effects and casualties. ${ }^{60}$

\section{Concluding remarks}

The chemical shells deployed in Gaza contained gases that would have been mentioned at least categorically in Dr. Süleyman Rifat's the toxicology lectures. If one considers that chemical warfare instructions were issued to Turkish officers in early 1916, and that the Ottoman Medical Faculty in Beirut was inaugurated in the same period, military mobilization and the contingency for chemical warfare could have alerted the faculty, as well as the students. Sümum ve Tesemmümat adresses the most common poisonings, which given the hygiene conditions of the environment, would have first and foremost been food poisonings. The text takes a still deeper view on the toxicity and pathology of certain poisonous gases, using carbon monoxide as a case study, and dwells on prevention with gas masks in various scenarios.

If there had been a team of experts with the mandate to investigate the human consequences of WWI gas warfare in Gaza, with his scientific qualifications and diligence Professor Dr. Süleyman Rifat would have been among them. Misfortunately, documents, reports and testimonies of these battles are all but lost to us, as the mysterious post-war years of Süleyman Rifat himself. Sümum ve Tesemmümat, can be read as a laboratory manual where the material and ethereal elements of those tragic and poisoned years of The Levant are brought together and explored in an academic milieu.

\section{Appendix: Contents of Sümum ve Tesemmümat}

Table 1. Poisoning with strong acids $(22.5 \times 35 \mathrm{~cm}$.)

1.1. Sulfuric acid

1.2. Nitric Acid

1.3. Hydrochloric acid

Table 2. Poisoning with strong organic acids $(22.5 \times 34 \mathrm{~cm}$.)

2.1. Oxalic acid (Hamız-ı hummaz)

2.2. Acetic acid

2.3. Formic acid

2.4. Phenic acid (Phenol)

60 A gas attack on the Gaza front is not mentioned even in the memoirs of a German intelligence officer: Oliver Stein, Nachrichtendienstoffizier im Osmanischen Reich: Ernst Adolf Muellers Kriegseinsatz und Gefangenschaft im Vorderen Orient, 1915-1919, mit einer kritischen Edition seiner Erinnerungen, Baden-Baden, Ergon Verlag, 2018, Istanbuler Texte und Studien, 41, 174-178. A US intelligence report on the Second Gaza Battle is similarly mute on the subject, Esat Arslan, 'Bir ABD istihbarat ajanının gözünden Suriye'deki IV. Ordu ve Gazze Muharebeleri (Fourth Army in Syria an Gaza Battles through the eyes of a US intelligence agent),' 1914'ten 2014'e 100'üncü Yllında Birinci Dünya Savaşını Anlamak, Uluslararasl Sempozyum, İstanbul, 20-21 Kasim 2014, ed. Zekeriya Türkmen, İstanbul, Harp Akademileri Komutanlığı Stratejik Araştırmalar Enstitüsü, 2015, s. 458-461 (Ek 3-4). 
Table 3. Poisoning with strong bases $(22.5 \times 34 \mathrm{~cm}$.)

3.1. Potasium and Sodium hydroxide (Potas ve sud muhrik)

3.2. Potasium carbonate (Fahmiyet-i potasyum)

3.3. Ammoniac

3.4. Quicklime (Kils-i muhrik)

3.5. Barite

Table 4. Poisoning with haloids ang halogens $(22.5 \times 34 \mathrm{~cm}$.)

4.1. Chlorine

4.2. Bromium

4.3. Iodine

Table 5. Poisoning with Arsenisc, Antimonies and Boron compounds (22.5x34 cm.)

5.1. Arsenics

5.2. Antimonies

5.3. Boron compounds

Table 6. Poisoning with heavy metals $(22.5 \times 39 \mathrm{~cm}$.)

6.1. Mercury

6.2. Silver

6.3. Chromium

6.4. Copper

6.5. Zinc

Table 7. Poisoning with metals $(22.5 \times 39 \mathrm{~cm}$.)

7.1. Tin

7.2. Lead

7.3. Bismuth

7.4. Phosphorus

Table 8. Intoxication with poisons affecting blood cells and other tissues $(22.5 \times 34 \mathrm{~cm}$.)

8.1. Hydrocyanic acid (Hamız-ı kiyanus ma)

8.2. Carbon monoxide (Humz-ı karbon)

8.3. Hydrogen sulfide (Kükürdlü müvellidü'l-ma)

Table 9.1. Poisons affecting the nervous system (narcotics) $(22.5 \times 34.5 \mathrm{~cm}$.)

9.1.1. Chloroform

9.1.2. Chloral

Table 9.2. Poisons affecting the nervous system (narcotics)

[muhaddir] (22.5 x $34.5 \mathrm{~cm}$.)

9.2.1. Alcohol

9.2.2. Opium and Morphine

Table 10. Poisons affecting the nervous system $(22.5 \times 39 \mathrm{~cm}$.)

10.1. Atropine

10.2. Nicotine

10.3. Muscarine and Pilocarpin

10.4. Conium and Cocain 
Table 11. Poisons causing nervous system excitation (convulsive poisons)

[sümum-ı asabiye-i muharrişiye (ihtilacat zehirleri)] (22.5 x $34 \mathrm{~cm}$.)

11.1. Cytisine ${ }^{61}$

11.2. Physostigmine (Eserine)

11.3. Conium and Coniine

11.4. Strychnine

11.5. Cicutoxin ${ }^{62}$

Table 12. Convulsive poisons [sümum-ı ihtilaciye] $(22.5 \times 44 \mathrm{~cm}$.)

12.1. Picrotoxin

12.2. Santonin

12.3. Aconitin

12.4. Colchicine

12.5. Veratrine

Table 13. Poisons affecting muscles and the nervous systems $(22.5 \times 34 \mathrm{~cm}$.)

13.1. Digitalis (Digitoxine)

13.2. Muscarine of mushrooms

Table 14. Intoxications caused by plants $(22.5 \times 44.5 \mathrm{~cm}$.)

14.1. Ergotism [Mahmuz tesemmümatı hastalığ $\breve{l}]$

14.2. Maidism (Maize disease, Pellegra) [Mısır tesemmümatı hastalığ $ı$ ]

14.3. Lathyrism [Hububat tesemmümatı hastalığı]

Table 15. Toxins of animals and insects $(22.5 \times 34 \mathrm{~cm}$.)

15.1. Cantharidine [Kuduz böceği hastalı̆̆l]

15.2. Frog toxins

15.3. Bee toxins

15.4. Spider toxins

15.5. Fish toxins

15.6. Snake and scorpion toxins

Table 16. Food poisoning $(22.5 \times 35 \mathrm{~cm}$.)

16.1. Sausages (Botulism) [Sucukla tesemmümat]

16.2. Meat

16.3. Cheese

16.4. Milk

Table 17. Internal (auto-)intoxications ${ }^{63}(22.5 \times 45 \mathrm{~cm}$.)

17.1. Ammoniaemia (ammoniémie)

17.2. Uremia (urémie)

17.3. Urataemia (uratémie)

17.4. Hydrothionurie (hydrothionurie [pneumaturia])

17.5. Glycosuria (glycosurie)

17.6. Alcaptanuria (alcaptanurie)

61 'Ihtilacat-ı tetanoziye' : tetanic muscle contractions.

62 'Sar'avi ihtilacat nöbeti': epileptic convulsions.

63 Author's note: Poisoning by toxines of pathogen microbes: diphteria, cholera, etc. infectious diseases are part of the pathological intoxications. 
Table 18 (Autonomous) ${ }^{64}$ Vegetative Nervous System $(22.5$ x $24.5 \mathrm{~cm}$.) Diagram and table: 'Pharmaco-toxicological substances affecting the vegetative nervous system'.

Table 19. (Autonomous) Vegetative Nervous System (22.5 x $24.5 \mathrm{~cm}$.)

Diagram

\section{BIBLIOGRAPHY / KAYNAKÇA}

Archival sources / Arşiv kaynakları

BOA (Başbakanlık Osmanlı Arşivi) DH.SAİDd.157/103.1302 Zilhicce 29 [9 Ekim $1885]$.

IRCICA FAV.00.00.03 (Dr. Ali Vehbi Türküstün koleksiyonu)

İBB Atatürk Kitaplığı Bel_Mtf_001694.pdf.

Private Archive: Title in Beirut c. 1925.

\section{Printed sources / Basılı kaynaklar}

Ahmed Djemal Pascha and Theodor Wiegand. Suriye ve Filistin ve Garbi Arabistan Abidat-ı Atikesi / Alte Denkmäler aus Syrien, Palästina und Westarabien. Berlin: Verlag Georg Reimer, 1918.

Alkan, Necati. "The Young Turks and the Baha'is in Palestine." In Late Ottoman Palestine: The Period of Young Turk Rule, edited by Yuval Ben-Bassat and Eyal Ginio, 259-278. London: I.B. Tauris, 2011.

Alkan, Necati. Dissent and Heterodoxy in the late Ottoman Empire: Reformers, Babis and Baha 'is. Istanbul, The Isis Press, 2008.

Arslan, Esat. "Bir ABD İstihbarat Ajanının Gözünden Suriye'deki IV. Ordu ve Gazze Muharebeleri." İçinde 1914'ten 2014'e 100'üncü Yılında Birinci Dünya Savaşını Anlamak, Uluslararasi Sempozyum, İstanbul, 20-21 Kasım 2014, edited by Zekeriya Türkmen, 435-461. İstanbul, Harp Akademileri Komutanlığı Stratejik Araştırmalar Enstitüsü, 2015.

Atasoy, Ali Rıza. Şam Türk Tıbbiye Mektebi Tarihi. İstanbul: İstanbul Üniversitesi Tıp Tarihi Enstitüsü, 1945.

Birinci Dünya Harbinde Türk Harbi, IV. Cilt I. Kısım, Sina - Filistin Cephesi, Harbin Başlangıcından Ikinci Gazze Muharebeleri Sonuna Kadar. Ankara: T.C. Genelkurmay Başkanlığı ATASE yay., Ankara, Genelkurmay Basımevi, 1979.

Dolev, Eran. Allenby's Military Medicine: Life and Death in World War I Palestine. London: I.B. Tauris, 2007.

Dölen, Emre. Eczacı Kimyager Anorganik ve Analitik Kimya Müderrisi Ligor Bey (1877-1956). Istanbul: Türkiye Kimya Derneği, 2017.

Dölen, Emre. Umumi Kimya Müderrisi Mustafa Hakkı Nalçacı (1881-1953). İstanbul: Türkiye Kimya Derneği, 2016.

64 Lit. Automatic. P1. 18 includes diagram and table entitled: 'Cümle-i asabiye-i nebatiyeye müessir cevahir-i farmako-toksikolojiye' (Pharmaco-toxicological substances affecting the vegetative nervous system). 
Gaz Muharebesi ve Gazlardan Korunma Hakkında Talimat, Neferata Mahsusdur. İstanbul: Matbaa-i Askeriye, 1332 [1916].

Gaz Muharebesi ve Gazlardan Korunma Hakkında Talimatname, Neferata mahsusdur, Harbiye Nezareti Sahra Sihhiye Müfettiş-i Umumiliği. İstanbul: Matbaa-i Askeriye, 1333 [1917].

Gruby, David. “Appareils et instruments de l'art médical (Études sur l'Exposition de 1867)." Annales et archives de l'industrie au XIXe siècle no. 36-37 (25 Janvier 1869): 277-296.

Hill, Jr., Benjamin A. "History of Medical Management of Chemical Casualties." In Medical Aspects of Chemical Warfare, edited by Shirley D. Tuorinsky, 77-114. Washington DC: Borden Institute, 2008.

Hurşid, Sait. Son Vapuru Kaçıranlar, yay. haz. M. Bülent Varlık. İstanbul: İletişim, 1999.

İhsanoğlu, Ekmeleddin. Al-Muassasat al-Sihhiyah al-Uthmaniyah al-Hadithah $f i$ Suriyah: al-Mustashfayat wa-Kulliyat Tibb al-Sham. Amman: Lajnat Tarikh Bilad alSham, 2002.

Kakule Talimatnamesi, edited by Süleyman Rifat. Beersheba ?, 1332[1916] ?.

Latimer, George O. The Light of the World. Boston: Self-published, 1920.

"Letter from Abbas Adib to Dr. Zia M. Bagdadi (Jan. 4, 1922)." Star of the West 12, no.

19 (March 2, 1922): 302.

Main, Steven J. "Gas on the Eastern Front during the First World War (1915-1917)." Journal of Slavic Military Studies 28, 1 (Jan.-March 2015): 99-132.

Sheffy, Yigal. "Asphyxiating Gas and the Gallipoli War: The Introduction of Chemical Warfare to the Middle East / Zehirli Gaz ve Çanakkale Savaşları: Kimyasal Savaş Yöntemlerinin Ortadoğu'da Kullanımın Başlangıc1.” In Gallipoli in Retrospect 90 Years On / 90. Yıldönümünde Çanakkale Savaşlarını Düşünürken, edited by A. Mete Tuncoku, 225-240. Çanakkale: Çanakkale Onsekiz Mart Üniversitesi Atatürk ve Çanakkale Savaşları Araştırma Merkezi, 2005.

Sheffy, Yigal. "The Chemical Dimension of the Gallipoli Campaign: Introducing Chemical Warfare to the Middle East." War in History 12, 3 (July 2005): 278-317.

Sheffy, Yigal. "Chemical Warfare and the Palestine Campaign, 1916-1918." The Journal of Military History 73, 3 (July 2009): 803-844.

Stein, Oliver. "Archeology and Monument Protection in War: The Collaboration between the German Army and Researchers in the Ottoman Empire, 1914-1918." In Militarized Cultural Encounters in the Long Nineteenth Century: Making War, Mapping Europe, 2018, edited by Joseph Clarke and John Hornes, 297-318. Cham: Palgrave Macmillan, 2018.

Stein, Oliver. Nachrichtendienstoffizier im Osmanischen Reich: Ernst Adolf Muellers Kriegseinsatz und Gefangenschaft im Vorderen Orient, 1915-1919, mit einer kritischen Edition seiner Erinnerungen, Istanbuler Texte und Studien, 41. Baden-Baden: Ergon Verlag, 2018. 
Süleyman Rifat, Müfredat-l Tıbdan En Mühim ve Kesir'ül-Vuku Sümum ve Tesemmümat Levhat-ı Tibbiyesi: Zehirler ve Zehirlenmeler (Tableaux des Poisons et Empoisonnements). Beyrut: Tabbara Matbaas1, 1334-1918.

Suleiman Rifàtwachdani. "Das Schiksal des Cocains und Ekgonins im Organismus." Biochemische Zeitschrift 54, 1/2 (1913): 83-91.

Wiegand, Theodor. Halbmond in Letzen Viertel. Briefe und Reiseberichte aus der alten Türkei von Theodor und Marie Wiegand 1895 bis 1918, edited by Gerhard Wiegand. München: Bruckmann, 1970.

Wiegand, Theodor. "Denkmalschutz und kunstwissenschaftliche Arbeit während des Weltkrieges in Syrien, Palästina und Westarabien." Zeitschrift für bildende Kunst (Leipzig) 54 (1918/19): 278-293.

Wissenschaftliche Veroffentlichungen des deutsch-türkischen DenkmalschutzKommandos, Heft I, edited by Theodor Wiegand. Berlin: W. de Gruyter, 1920.

Yıldırım, Nuran. "Osmanlı Ordusunda Kakule Sıhhiye Bölükleri.” İçinde V. Türk Tıp Tarihi Kongresi Bildirileri (Ankara, 16-18 Mart 1998), editörler Esin Kahya, Sevgi Şar, Adnan Ataç, N. Yasemin Oğuz, Berna Arda, 163-187. Ankara: Ankara Üniversitesi, Gülhane Askeri Tıp Akademisi, Türk Tıp Tarihi Kurumu, 1999.

Zabitana Mahsus Gaz Muharebesi ve Gazlardan Korunma Hakkında Talimat. İstanbul: Matbaa-i Askeriye, 1332 [1916].

\section{Electronic texts / Elektronik metinler}

Tekiner, Halil, İ. İpek Boşgelmez, Gülin Güvendik, Ayşe Eken, Burcu Ünlü Endirlik, Emre Dölen, “Türkiye'de 1920 'den günümüze kadar basılmış olan toksikoloji ders kitaplarının içerik ve terminoloji bakımından incelenmesi." XI. Türk Eczacılık Tarihi Toplantısl, Kayseri, 25-28 Mayls 2014, Bildiriler / XI. National Conference on the History of Turkish Pharmacy, Kayseri, 25-28 May 2014, Proceedings içinde, editörler Afife Mat ve Halil Tekiner, 164-171. Kayseri: Erciyes Üniversitesi Eczacilık Fakültesi, 2016 [e-book].

Star of the West 12, 1 (1921). https://s3.amazonaws.com/starofthewest/SW_Volume12.pdf 